\begin{tabular}{|l|l|l||}
\hline \multicolumn{2}{|c|}{ PublisherInfo } \\
\hline \hline PublisherName & $:$ & BioMed Central \\
\hline \hline PublisherLocation & $:$ & London \\
\hline \hline PublisherImprintName & $:$ & BioMed Central \\
\hline \hline
\end{tabular}

\title{
Proteomic early detection of ovarian cancer
}

\begin{tabular}{|l|l|l||}
\hline \multicolumn{2}{|c|}{ ArticleInfo } \\
\hline \hline ArticleID & $:$ & 4399 \\
\hline \hline ArticleDOI & $:$ & $10.1186 /$ gb-spotlight-20020213-01 \\
\hline \hline ArticleCitationID & $:$ & spotlight-20020213-01 \\
\hline \hline ArticleSequenceNumber & $:$ & 65 \\
\hline \hline ArticleCategory & $:$ & Research news \\
\hline \hline ArticleFirstPage & $:$ & 1 \\
\hline \hline ArticleLastPage & $:$ & 2 \\
\hline \hline & & RegistrationDate : 2002-2-13 \\
\hline ArticleHistory & $:$ & OnlineDate \\
\hline \hline ArticleCopyright & $:$ & BioMed Central Ltd2002-13 \\
\hline \hline ArticleGrants & $:$ & \\
\hline \hline ArticleContext & $:$ & 130593311 \\
\hline \hline
\end{tabular}




\section{Tudor Toma}

Email: t.toma@ic.ac.uk

Over $80 \%$ of ovarian cancers are diagnosed when the disease is at a late stage, with a consequent fiveyear survival rate of only around $35 \%$. New technologies for the detection of early-stage ovarian cancer would therefore be of great benefit. In February 8 online edition of The Lancet, Emanuel Petricoin III and colleagues from the US Food and Drug Administration, Bethesda, show that computer-assisted detection of proteomic patterns could help in screening for ovarian cancer.

Petricoin et al. analysed blood proteins of women with ovarian cancer using mass spectroscopy and a novel computer-searching algorithm. They found a discriminatory proteomic pattern that correctly identified all 50 ovarian cancer cases and 63 of the 66 non-cancer cases from a set of 116 masked serum samples (sensitivity 100\%; specificity 95\%; positive predictive value 94\%; Lancet 2002, 359:572-577).

"These findings justify a prospective population-based assessment of proteomic pattern technology, as a screening tool for all stages of ovarian cancer in high-risk and general populations," commented Emanuel Petricoin III.

\section{References}

1. Petricoin III EF, Ardekani AM, Hitt BA, Levine PJ, Fusaro VA, Steinberg SM, Simone GS, Fishman DA, Kohn EC, Liotta LA: Use of proteomic patterns in serum to identify ovarian cancer. Lancet 2002, 359:572-577. , [http://www.thelancet.com]

2. Food and Drug Administration, [http://www.fda.gov]

This PDF file was created after publication. 